\title{
Aegle Marmelos (L.) Correa, A Potential Source for the Treatment of Diabetes Associated Alzheimer's Disease: A
}

\section{Review}

\section{Jannat $\mathbf{K}$, Jahan $\mathbf{R}$ and Rahmatullah $\mathbf{M}^{*}$}

Department of Biotechnology \& Genetic Engineering, University of Development Alternative, Bangladesh

*Corresponding author: Professor Mohammed Rahmatullah, Dean, Faculty of Life Sciences, University of Development Alternative, Lalmatia, Dhaka-1207, Bangladesh, Tel: +88-01715032621; Email: rahamatm@hotmail.com

\section{Review Article \\ Volume 3 Issue 4}

Received Date: September 23, 2019

Published Date: October 16, 2019

DOI: $10.23880 /$ oajpr-16000186

\section{Abstract}

Alzheimer's disease is a chronic neurodegenerative disorder leading to memory loss, which is caused by progressive wasting away of brain cells. Memory loss leads to changes in a person's behavior, thinking and social skills leading in turn to profound alterations in a person's social and family life. The disease can occur by itself with age; however, onset of diabetes can precipitate the onset of the disease or augment the disease process and symptoms. Current allopathic medications can only improve the symptoms of Alzheimer's disease, albeit temporarily and cannot cure the disease. According to the World Health Organization, about 44 million people were suffering from the disease in 2015, a number likely to go up to 114 million by 2050 causing severe strains in family relationships and finances. Plants are a potential source of stopping the development of Alzheimer's or even curing the disease. The present review examines the potential of a plant Aegle marmelos or Bengal quince in the treatment of Alzheimer's disease.

Keywords: Alzheimer' disease; Aegle marmelos; Bengal quince; Dementia; Diabetes

\section{Introduction}

Alzheimer's disease (AD), a chronic neurodegenerative disease is the most common form of dementia characterized by the symptom of short-term memory loss (difficulty in remembering recent events). This condition occurs due to death of brain cells. The disease was first identified and described by a German psychiatrist and neuropathologist Dr. Alois Alzheimer after whom the name was given $[1,2]$. The prevalence of this disease in contemporary times is in higher progression. An account shows that in 2015 about 44 million of people mostly over 60 years of age were suffering from AD [3]. World Health Organization (WHO) has recently estimated the number of $\mathrm{AD}$ patients for 2050 in which the number amplifies to 114 million [4].

Two pathologies are thought to be responsible for the progression of the disease- $\beta$-amyloid plaque deposition (build up in the spaces between nerve cells) and 


\section{Open Access Journal of Pharmaceutical Research}

neurofibrillary tangles (build up inside the cells) of hyperphosphorylated tau. $\beta$-Amyloid protein is a fragment from an amyloid precursor protein, which in normal brain is broken down but in AD the fragments accumulate to form hard plaques. In normal brains, tau proteins bind to and stabilize microtubules; during $\mathrm{AD}$, tau proteins stick to each other causing the tangles. People generally grow plaque and tangles in their brain during their old age but diagnosis showed that $\mathrm{AD}$ patient have a greater tendency to develop these two in their brain. These formations begin in the memory region prior to spread in the others. Scientists believe that development of plaque and tangle has a role on disabling or blocking the communication among nerve cells and they can even damage the process needed for their survival. This disruption of nerve cells causes memory loss, which turns into Alzheimer's disease [5-7]. To understand the etiology of $\mathrm{AD}$, a variety of hypotheses has been made with different degrees of support from epidemiological, clinical and experimental data; these hypotheses include amyloid hypothesis, tau hypothesis, cholinergic hypothesis (deficit of acetylcholine, a neurotransmitter that conduct electrical impulses among nerve cells by rapid hydrolysis by acetyl-cholinesterase); vascular hypothesis (depletion of cerebral blood flow), mitochondrial cascade hypothesis which describes mutations in mitochondrial DNA, oxidative stress, and presence of amyloid $b$ peptide in mitochondria that induces mitochondrial dysfunction and apoptosis of nerve cells leading to AD. Another hypothesis related to metabolic dysfunction or changes in metabolic processes has also been put forth. Diseases like obesity, type 2 diabetes mellitus, hypercholesterolemia also can be cause of Alzheimer's disease [8].

Nowadays, neuropathy is mostly occurring in diabetic patients. Scientists have figured out that there is a connection between these two chronic diseases. The prevalence of this connection is yet to be completely figured out. However, the evidence is increasing of a correlation between diabetes and AD [9-12]. Several studies were done to show the risk factors of developing AD from diabetes. A study was conducted by taking 6,370 elderly people who were under observation for 2.5 years. When the result came out, 126 subjects were found having developed dementia and surprisingly 89 of these were diagnosed with diabetes; notably, increased oxidative stress is a common factor in the pathogenesis of both diseases [13]. People with diabetes are more sensitive to develop AD in their later life. In a recent study researchers have found that there is a relation between growing of amyloid plaque and loss of $b$ cells of islet (insulin producing cells) [14]. Mechanism of diabetes and $\mathrm{AD}$ is a riddle; neuroinflammation, oxidative stress [15], amyloid accumulation [16] and mitochondrial dysfunction provoke brain insulin resistance which leads to amyloid $\mathrm{b}$ accumulation in brain. Exposure to hyperglycemia and hyperinsulinemia in addition with amyloid $b$ accumulation for a long period causes neuronal deterioration of structure and function $[17,18]$. Reasons and risk factors are shown in Figure 1.

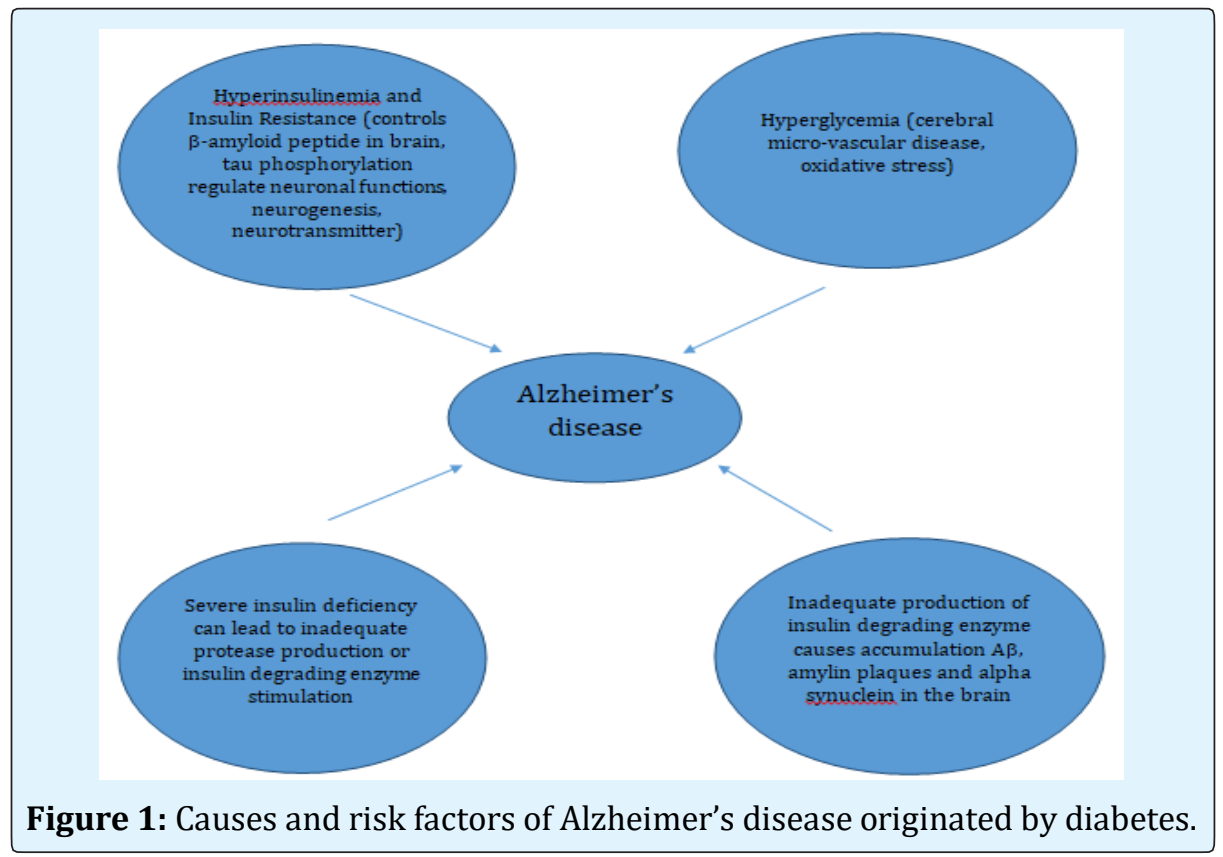




\section{Open Access Journal of Pharmaceutical Research}

An acceptable theory was established by a recent study which supported the importance of insulin and insulin-like growth factor (IGF-1) in modulating brain function and cognitive process. Insulin enters into the central nervous system through blood brain barrier by a process called saturable receptor mediated process. Insulin transportation becomes slow in $\mathrm{AD}$ patient and normally aged person. Location of insulin receptors in the hippocampus, entorhinal cortex, and frontal cortex proves that insulin has a vital role in learning and remembering [19]. This condition (AD) caused by insulin resistance in brain is now often known as type 3 diabetes $[20,21]$.

Currently, AD has no treatment for cure and therefore, the burden of the disease is rising to an epidemic proportion. Various clinical trials have been done already but most of them gave disappointing results [22]. Moreover, the treatments are not cost effective. Natural compounds isolated from plants and animals were investigated against the disease as alternative mode of treatment and found effective for the treatment of $\mathrm{AD}$. Natural extract made from plants are in clinical trials for treatment of different $\mathrm{AD}$ conditions (mild to moderate, severe, severe $A D$, vascular dementia etc.); the various plants or plant products tested include Ginkgo biloba, saffron, coconut, green tea, lemon balm, sage, blueberry and some others [23]. Aegle marmelos (L.) Correa commonly known as bael (in Bengali) and Bengal quince or goilden apple (in English) has been used in Ayurveda and folk medicine of Bangladesh for over 500 years for the treatment of various diseases comprising diabetes and memory loss [24]. The plant has been used for retrieving memory or enhancing the capability of remembering that was deteriorated because of diabetes. The rest of the review will focus on the pharmacological properties and phytochemicals present in the plant and discuss the potential of the plant or its various parts in the treatment of diabetes-induced AD.

\section{Aegle marmelos (L.) Correa}

Aegle marmelos is a moderate sized $(6-8 \mathrm{~m})$, slender, aromatic tree of Rutaceae family. The plant is indigenous in Southeast Asian countries. It is commonly known as bael in Bengali. Almost all parts of the plant are used for medicinal purposes like stem, bark, fruit, leaf, seed, seed oil, root, flower etc. Bael is considered as a holy plant among the Hindu community $[25,26]$.

\section{Phytochemicals}

Chemicals present in different plant parts are mainly secondary metabolites. Medicinal properties of plant are usually regulated and specified by these chemicals. Secondary metabolites not only give a plant the capability of curing disease, it provides a defense against various external threats $[27,28]$. Alkaloids, tannins, coumarins, steroids, polysaccharides, carotenoids have been isolated from individual parts of the plant (Aegle marmelos). Aegle marmelos leaves are rich in g-sitosterol, aegelin, lupeol, rutin, marmesinin, b-sitosterol, flavone, glycoside, $O$ isopentenylhalfordiol, marmelin, and phenylethyl cinnamamides [29]. Various phytochemicals present in Aegle marmelos are shown in Table 1.

\begin{tabular}{|c|c|c|}
\hline Alkaloids & Plant parts & References \\
\hline 0-3,3-(dimethylallyl)halfordinol & Leaf & {$[30]$} \\
\hline N-2-ethoxy-2-(4-methoxyphenyl) ethylcinnamamide & Leaf & {$[30]$} \\
\hline N-2-methoxy-2-[4-(3',3'-dimethylallyloxy)phenyl] ethylcinnamamide & Leaf & {$[30]$} \\
\hline N-2-methoxy-2-(4-methoxyphenyl) ethylcinnamamide & Leaf & {$[30]$} \\
\hline N-2-hydroxy-2-[4-(3',3'-dimethylallyloxy)phenyl] ethylcinnamide or \\
marmeline & Leaf & {$[30]$} \\
\hline N-4-methoxystyryl cinnamide & Leaf & {$[30]$} \\
\hline N-2-hydroxy-2-(4-hydroxyphenyl) ethylcinnamide & Leaf & {$[30]$} \\
\hline Anhydromarmeline & Leaf & {$[29,30]$} \\
\hline Aegelinosides A & Leaf & {$[29,30]$} \\
\hline Aegelinosides B & Leaf & {$[29,30]$} \\
\hline marmelos & Dry Leaf & {$[30]$} \\
\hline N-2-hydroxy-2-(4-methoxyphenyl)-ethylcinnamamide (aegeline) & Leaf, root & {$[30]$} \\
\hline 4,7,8-trimethoxy-furoquinoline (skimmianine) & Leaf, root & {$[30]$} \\
\hline N-2-ethoxy-2-ethyl cinnamid & Leaf & {$[31,32]$} \\
\hline Aeglenine & Leaf & {$[31,32]$} \\
\hline
\end{tabular}




\section{Open Access Journal of Pharmaceutical Research}

\begin{tabular}{|c|c|c|}
\hline \multicolumn{3}{|c|}{ Terpenoids } \\
\hline Terpenoids & Plant parts & References \\
\hline Lupeol & Root bark & [32] \\
\hline a-Phellandrene & Leaf oil & {$[30,31,47]$} \\
\hline p-Cymene & Leaf oil & {$[30,31]$} \\
\hline p-Menth-1-en-3,5-diol & Leaf & {$[30,31,33]$} \\
\hline Limonene & Leaf & {$[30,31,33]$} \\
\hline g-Sitosterol & Leaf & {$[30,31]$} \\
\hline a \& b-Amyrin & Leaf, stem bark, root, fruit & {$[30,31]$} \\
\hline b-Sitosterol & Leaf, stem bark, root, fruit & {$[30,31]$} \\
\hline a- Pinene & Leaf, twig, fruit & [33] \\
\hline b-Myrcene & Whole plant & [31] \\
\hline b-Ocimene & Whole plant & [31] \\
\hline d-Carene & Whole plant & [31] \\
\hline Isosylvestrene & Whole plant & [31] \\
\hline \multicolumn{3}{|c|}{ Flavonoids } \\
\hline Chemicals & Plant parts & References \\
\hline Rutin & Leaf & [31] \\
\hline Flavon-3-ol & Whole plant & {$[31]$} \\
\hline Flavon glycosides & Whole plant & [31] \\
\hline \multicolumn{3}{|c|}{ Coumarins } \\
\hline Coumarins & Plant parts & References \\
\hline Psoralen & Root & {$[32,33,47]$} \\
\hline Xanthotoxin & Root, root bark & [32] \\
\hline Dimethoxycoumarin & Root & [32] \\
\hline Scopoletin & Root & {$[32,33,47]$} \\
\hline Urbelliferone & Root, root bark & {$[33,34]$} \\
\hline Marmesin & Root, root bark & {$[31,32,47]$} \\
\hline Marmin & Root & {$[32,33,47]$} \\
\hline Skimmin & Root & [32] \\
\hline Imperatorin & Whole plant & [31] \\
\hline Marmelide & Whole plant & [31] \\
\hline Alloimperatorin & Whole plant & [33] \\
\hline \multicolumn{3}{|c|}{ Essential oils } \\
\hline Chemicals & Plant part & References \\
\hline a- Pinene & Leaf & {$[34,35]$} \\
\hline b- Myrcene & Leaf & [34] \\
\hline a- Phellandrene & Leaf & {$[34,35]$} \\
\hline Isosylvestrine & Leaf & [34] \\
\hline d- Careen & Leaf & [34] \\
\hline b-Ocimene & Leaf & {$[34,35]$} \\
\hline trans-2-hydroxycinnmic acid & Leaf & {$[34]$} \\
\hline Terpenolene & Leaf & [34] \\
\hline Linalool & Leaf & [34] \\
\hline 3-isothujanol & Leaf & [34] \\
\hline 4-Terpineol & Leaf & [34] \\
\hline a -Terpineol & Leaf & [34] \\
\hline Thuj-3-en-10-al & Leaf & {$[34]$} \\
\hline d \& g-Elemene & Leaf & [34] \\
\hline a -Cubebene & Leaf & [34] \\
\hline
\end{tabular}




\section{Open Access Journal of Pharmaceutical Research}

\begin{tabular}{|c|c|c|}
\hline Valencene & Leaf & {$[34]$} \\
\hline b-Selinene & Leaf & {$[34]$} \\
\hline a-Duprezianene & Leaf & {$[35]$} \\
\hline Caryophylline & Leaf & {$[35]$} \\
\hline b-Elemene & Leaf & {$[35]$} \\
\hline Germacrene & Leaf & {$[35]$} \\
\hline (3Z)-Hexenylhexanoate & Leaf & {$[35]$} \\
\hline iso-3-Thujanyl acetate & Leaf & {$[35]$} \\
\hline L-Atlantol Leaf & {$[35]$} \\
\hline \multicolumn{1}{|c|}{ Miscellaneous compounds } & References \\
\hline Chemicals & Plant parts & {$[30]$} \\
\hline Praealtin D & Leaf & {$[30]$} \\
\hline trans-cinnamic acid & Leaf & {$[30]$} \\
\hline 4-methoxybenzoic acid & Leaf & {$[30]$} \\
\hline montanine, rutaretin & Leaf & {$[30]$} \\
\hline
\end{tabular}

Table 1: Phytochemicals reported in Aegle marmelos.

\section{Ethnomedicinal Use of Bael in Enhancing Memory and Treatment of Diabetes}

In Ayurvedic treatment of neuropathy Aegle marmelos fruits have been in use to enhance memory for over 1500 years. Among folk medicine practitioners of Bangladesh, this plant is quite popular as a memory enhancer [36]. Bangladesh folk medicine practitioner use the plant leaves to increase memory. Leaves are fried in a little ghee (clarified butter) and advised to take orally with honey to increase memory [37].

Aegle marmelos is a well-known medicinal plant among Ayurveda and Siddha system for the treatment of diabetes. Its leaves are highly antidiabetic [38]. The Loi community of Manipur, Northeast India eats tender raw leaves with milk to treat diabetes [39]. Indigenous people of Nalbari district, Assam take the leaf powder with cow's milk daily in order to cure diabetes [40]. Decoction made from leaves is orally taken on an empty stomach every morning in Nepal [41]. The poor people of Kerala also use bael leaves to treat diabetes. They grind the leaves, make it into small pills and orally take once a week [42]. A combination three plant parts work as antidiabetic. Powder of leaves of Aegle marmelos, seed powder of Azadirachta indica and Syzygium cumini are mixed together with water which is then orally taken twice a day [43]. Folk medicine practitioners as well as native people of Bangladesh use this plant for the treatment of diabetes. Leaf juice is drunk by the people of Brahmanbaria district [44]. A tradition of chewing and swallowing leaves of bael every morning is very common among the Paliyars tribe,

Rahmatullah M, et al. Aegle Marmelos (L.) Correa, A Potential Source for the Treatment of Diabetes Associated Alzheimer's Disease: A Review. Pharm Res 2019, 3(4): 000186.
Tamil Nadu, India [45]. Drug obtained by distillation of flowers is used for the treatment of diabetes [46].

\section{Pharmacological Evidence}

Aegle marmelos is a potential alternate to treat Alzheimer's disease or to enhance remembering capability [47]. A number of investigations have been done already. Mice, that were given different doses (100, $200,400 \mathrm{mg} / \mathrm{kg}$ oral) of methanolic leaf extract of bael fruits showed significant progress of remembering as examined through Morris Water Maze method and Pole Climbing test. Mice were at first treated with scopolamine to induce memory impairment [48]. Another experiment was designed with Wistar Albino rats. They were administered ethanolic extract of leaf at the doses of 200 and $400 \mathrm{mg} / \mathrm{kg}$ for 14 days; streptozotocin $(3 \mathrm{mg} / \mathrm{kg})$ was injected to rats on $1^{\text {st }}$ and $3^{\text {rd }}$ day of the experiment. After three weeks of administering streptozotocin, biochemical and histopathological studies were carried out, which revealed increase in level of oxidative stress marker malondialdehyde, nitrite, acetylcholinesterase activity (indicates cholinergic hypofunction and neuronal damage) and decrease in glutathione level. All these were ameliorated by extract of bael leaf which proved the tree has therapeutic value in treating $\mathrm{AD}[36,49]$.

Acetylcholinesterase inhibition and antioxidant properties were checked with methanolic extract of leaf and four solvent fractions of petroleum ether, chloroform, ethyl acetate and water. Among them ethyl acetate fraction gave an outstanding result in acetylcholinesterase inhibition activity performed by 


\section{Open Access Journal of Pharmaceutical Research}

Ellman method and reducing oxidation; the fraction also demonstrated radical scavenging activity of 1,1-diphenyl-2-picrylhydrazyl and inhibited lipid peroxidation in brain as well. The fraction was a rich source of polyphenolic compounds, which were considered responsible for showing all these activities and hence considered to be helpful for the treatment of Alzheimer's disease [50,51].

To evaluate anti-amnesic activity of Aegle marmelos, leaves were taken and extracted with ethanol. Adult male albino rats were exposed to electroshock (MES) and scopolamine to produce loss of memory. Chronic exposure resulted in significant decrease and increase in latency time measured by step down latency and transfer latency in elevated maze respectively. Scopolamine exposure showed increase in acetylcholinesterase activity. By treating with ethanol extract of leaf all these symptoms were ameliorated significantly $(\mathrm{P}<0.01)$ [52]. It was stated before that every part of the plant possess therapeutic value. Not only leaves of this plant are used to treat $\mathrm{AD}$, but also fruits and seeds are used. Methanolic extract of fruits showed nootropic effect that was tested on three groups of Wistar Albino rats by Morris water maze. Both the scopolamine treated and without scopolamine group showed significant increase in memory [53]. Dried fruit extracts (doses $200 \mathrm{mg} / \mathrm{kg}$ and $400 \mathrm{mg} / \mathrm{kg}$ ) also showed effective result against cognitive defects mainly Alzheimer's disease [54]. A comparison of nootropic effect was shown between Aegle marmelos extract and standard drug Piracetum. An experiment was conducted by taking male Wistar rats divided into four groups, each group comprised of six rats. Group two, three and four were treated with extract at $100 \mathrm{mg} / \mathrm{kg}$, $200 \mathrm{mg} / \mathrm{kg}$ and $200 \mathrm{mg} / \mathrm{kg}$, respectively, for seven consecutive days. Assessing learning and memory by elevated plus maze method showed that both doses showed significant decrease in transfer latency from 6th day to 7 th day $(\mathrm{p}<0.05)[55]$.

Beneficial effects on AD or causes like diabetes leading to $\mathrm{AD}$ can be obtained individually or in combination through treatment of memory loss, diabetes, and oxidative stress. Aegle marmelos can be a treatment of diabetes as well [56]. There are plenty of evidences that support this statement. Antidiabetic effects of the plant and plant parts as well as any reported responsible phytochemicals are shown in Table 2.

\begin{tabular}{|c|c|c|c|}
\hline Extract or active compound & Experiment model & Effect on diabetes & Reference \\
\hline Hydroalcoholic extract of roots & $\begin{array}{l}\text { Alloxan-induced diabetic } \\
\text { mice }\end{array}$ & Significantly $(\mathrm{P}<0.05)$ lessened blood glucose level. & [57] \\
\hline $\begin{array}{c}\text { Aegeline (N-acylated-1-amino- } \\
\text { 2- alcohol) from leaves }\end{array}$ & In-vitro & $\begin{array}{c}\text { Increased insulin sensitivity by activation of b3-AR } \\
\text { pathway. (AR stands for adrenergic receptor) }\end{array}$ & [58] \\
\hline Extract of fruits and leaves & $\begin{array}{c}\text { Streptozotocin } \\
\text { (90mg/kg) induced } \\
\text { diabetic Long Evans Rats }\end{array}$ & Lowered insulin resistance. & [59] \\
\hline Leaf extract & \begin{tabular}{|c|} 
Streptozotocin \\
(90mg/kg) induced \\
diabetic Long Evans Rats
\end{tabular} & $\begin{array}{l}\text { Significantly }(\mathrm{P}<0.05) \text { increased insulin secretion, a- } \\
\text { amylase and intestinal disaccharidase enzyme } \\
\text { activities, reduced glucose absorption. }\end{array}$ & {$[60]$} \\
\hline $\begin{array}{l}\text { Aegeline ( } \mathrm{N} \text {-acylated-1-amino- } \\
\text { 2-alcohol) from leaves }\end{array}$ & In-vitro & $\begin{array}{l}\text { Increased peripheral insulin sensitivity by stimulating } \\
\text { PI3-kinase-Rac1-PAK1-cofilin pathway which was } \\
\text { mediated by two distinct but parallel pathways Akt } \\
\text { and Rac1 to stimulate glucose transporter. }\end{array}$ & [61] \\
\hline $\begin{array}{c}\text { Umbelliferone } \beta \text {-D- } \\
\text { galactopyranoside from stem } \\
\text { bark }\end{array}$ & $\begin{array}{c}\text { Streptozotocin } \\
\text { (60mg/kg) induced Swiss } \\
\text { Albino Wistar rats }\end{array}$ & $\begin{array}{c}\text { Increased level of pancreatic insulin secretion and } \\
\text { antioxidant activity. }\end{array}$ & {$[62]$} \\
\hline Methanolic extract of bark & \begin{tabular}{|c|} 
Streptozotocin \\
(60mg/kg) induced male \\
Swiss Albino Wister rats
\end{tabular} & $\begin{array}{l}\text { Significantly reduced blood glucose level, increased } \\
\text { regeneration of pancreatic b cells. }\end{array}$ & {$[63]$} \\
\hline Methanolic extract of leaves & In-vitro & Inhibited a-amylase activity. & [64] \\
\hline Ethanolic extract of leaves & $\begin{array}{c}\text { Streptozotocin } \\
\text { (55mg/kg) induced male } \\
\text { Swiss Albino Wistar rats }\end{array}$ & $\begin{array}{l}\text { Initialized regeneration of Islet cells and increase in } \\
\text { the islet cells compared to the diseased pancreas. }\end{array}$ & {$[65]$} \\
\hline Umbelliferone (7- & Streptozotocin & Improved glycemic control resulting in reduced & [66] \\
\hline
\end{tabular}




\section{Open Access Journal of Pharmaceutical Research}

\begin{tabular}{|c|c|c|c|}
\hline hydroxycoumarin) from fruit & $\begin{array}{c}(40 \mathrm{mg} / \mathrm{kg}) \text { induced Swiss } \\
\text { Albino Wistar rats }\end{array}$ & $\begin{array}{l}\text { formation of circulatory and tissue glycoprotein } \\
\text { components. }\end{array}$ & \\
\hline Aegeline 2 from leaves & $\begin{array}{c}\text { Streptozotocin } \\
\text { (100mg/kg) induced } \\
\text { Swiss Albino Wistar rats }\end{array}$ & $\begin{array}{c}\text { Significantly decreased blood glucose level, may have } \\
\text { activity as b3-AR agonist. }\end{array}$ & [67] \\
\hline Aqueous extract of seeds & \begin{tabular}{|l|} 
Diabetic rats \\
\end{tabular} & Increased glucose tolerance. & [68] \\
\hline Aqueous extract of leaves & $\begin{array}{l}\text { Alloxan induced diabetic } \\
\text { rats }\end{array}$ & $\begin{array}{c}\text { Lowered blood glucose level, decreased glutathione-S- } \\
\text { transferase and malondialdehyde, increase in } \\
\text { glutathione which indicates hypoglycemic and } \\
\text { antioxidant activity. }\end{array}$ & [69] \\
\hline Aqueous extract of fruits & $\begin{array}{c}\text { Streptozotocin } \\
\text { (45mg/kg) induced } \\
\text { diabetes in female Swiss } \\
\text { Albino Wistar rats } \\
\end{array}$ & Decreased plasma insulin level. & [70] \\
\hline Anhydroageline & In-vitro & Inhibitory effect against a-glucosidase. & [71] \\
\hline
\end{tabular}

Table 2: Antidiabetic effects of the plant along with any reported responsible phytochemical.

Concurrent epidemiological studies strongly supports that diabetes remarkably increases the risk of developing AD. In addition, both insulin and insulin like growth factor 1 (IGF-1) have been found in reduced amount in the brain of $\mathrm{AD}$ patients and most of the patients developed diabetes or glucose intolerance [72,73]. Different antidiabetic compounds have already been investigated against $\mathrm{AD}$ which revealed significantly beneficial results [74]. In a study done by Vandal et al., they genetically induced AD-like neuropathology in mouse fed with high fat diet, which led to peripheral glucose intolerance with pancreatic human $A \beta$ (amyloid beta) accumulation, enhanced brain soluble $A \beta$, and memory impairment in 3xTg-AD mice. But a single dose of insulin injection reverted the effect of high fat diet and reduced the amount of brain soluble $A \beta$ and enhanced memory [75]. Treating APPSWE/PS1dE9 mice with an analogue Liraglutide (glucagon like peptide 1) that was approved for the treatment of type II diabetes, significantly lessened IRS-1pS (616) that is the insulin receptor substrate (IRS)1 phosphorylated at serine 616 . It also decreased the amount of amyloid plaque formation and glia cells associated to amyloid loads [76]. Cognitive function was improved by inhibiting cyclin-dependent kinase 5 (cdk 5) activities by treating APPSWE/PS1dE9 mice with pioglitazone $(10 \mathrm{mg} / \mathrm{kg})$ [77]. Another antidiabetic drug lixisenatide restored cognitive and synaptic function when it was given to APPSWE/PS1dE9 mice by reducing Ab pathology [78].

Considering the beneficial nootropic effect of antidiabetic agents and as Aegle marmelos has antidiabetic properties, it can be stated that this plant has the potency to treat $\mathrm{AD}$ in diabetic patients. Aqueous extract of seeds of Aegle marmelos was administered to streptozotocin induced diabetic Wistar rats at doses of 100,250 and $500 \mathrm{mg} / \mathrm{kg}$. A sharp improvement of spatial learning and memory was noticed between control and treated mice. Swimming time or escape latency was significantly lower $(\mathrm{P}<0.01)$ in extract treated groups than control; on the other hand swimming speed was remarkably higher $(\mathrm{P}<0.05)$ than control in Aegle marmelos extract treated groups [79-81].

\section{Conclusion}

Overall, the results quite conclusively suggest that antidiabetic drugs can have beneficial effects on diabetesinduced AD. Diabetes can lead to AD in multiple ways as shown in Figure 1. At the same time, oxidative stress is both a consequence and a factor leading to diabetes. Thus the solution to diabetes-induced AD might lie in a drug which combines memory enhancing, antidiabetic and antioxidant properties.

\section{Acknowledgement}

The authors are grateful to MM Maidul Islam and NA Shova for providing information on the plant.

\section{Conflict of Interest}

The authors declare that there are no conflicts of interest.

\section{References}

1. Khyade BV, Khyade VS, Jagtap GS (2016) Alzheimer's disease: overview. Int Acad J Soc Sci 3(12): 23-28. 


\section{Open Access Journal of Pharmaceutical Research}

2. Bhushan I, Kour M, Kour G, Gupta S, Sharma S, et al. (2018) Alzheimer's disease: causes and treatment- a review. Ann Biotechnol 1(1): 1002.

3. Cauwenberghe VC, Broeckhoven VC, Sleegers K (2016) The genetic landscape of Alzheimer's disease: clinical implications and perspectives. Genet Med 18(5): 421-430.

4. Alzheimer's Association (2015) Alzheimer's disease facts and figures Alzheimer's Association, Alzheimer's \& Dementia 11(3): 332-384.

5. Weller J, Budson A (2018) Current understanding of Alzheimar's disease diagnosis and treatment. F1000Res.

6. (2019) Alzheimer's association.

7. De A, Bala NN, Gupta DP (2011) Alzheimer's disease and its management. Int J Res Pharm Biomed Sci 2(4): 1439-1443.

8. Mendiola-Précoma J, Rodríguez-Cruz A, Berumen L, García-Alcocer G (2016) The etiology of Alzheimer's desease. Neurobiology pp: 1-12.

9. Wang CY, Neil DL, Home P (2018) 2020 vision - an overview of prospects for diabetes management and prevention in the next decade. Diabetes Res Clin Pract 143: 101-112.

10. Brookmeyer R, Abdalla N, Kawas CH, Corrada MM (2018) Forecasting the prevalence of preclinical and clinical Alzheimer's disease in the United States. Alzheimers Dement 14: 121-129.

11. Rojas-Carranza CA, Bustos-Cruz RH, Pino-Pinzon CJ, Ariza-Marquez YV, Gomez-Bello RM, et al. (2018) Diabetes related neurological implications and pharmacogenomics. Curr Pharm Des 24(15): 16951710.

12. Li J, Cesari M, Liu F, Dong B, Vellus B (2017) Effect of diabetes mellitus on cognitive decline in patients with Alzheimer's disease: A systematic review. Can J Diabetes 41(1): 114-119.

13. Kroner $Z$ (2009) The relationship between Alzheimer's disease and diabetes: type 3 diabetes? Altern Med Rev 14(4): 373-379.

Rahmatullah M, et al. Aegle Marmelos (L.) Correa, A Potential Source for the Treatment of Diabetes Associated Alzheimer's Disease: A Review. Pharm Res 2019, 3(4): 000186.
14. Janson J, Laedtke T, Parisi JE, O’Brien P, Petersen RC, et al, (2004) Increased risk of type 2 diabetes in Alzheimer's disease. Diabetes 53(2): 474-481.

15. Rosales-Corral S, Dun-Xian T, Manchester L, Reiter JR (2015) Diabetes and Alzheimer's disease, two overlapping pathologies with the same background: oxidative stress. Oxidative Medicine and Cellular Longevity pp: 1-14.

16. Grizzanti J, Corrigan R, Servizi S, Casadesus G (2019) Amylin signaling in diabetes and Alzheimer's disease: Therapy or pathology?. J Neurol Neuromedicine 4(1): 12-16.

17. Lee JH, Seo IH, Cha YH, Yang JY, Kwon HS, Yet al, (2018) Diabetes and Alzheimer's disease: mechanisms and nutritional aspects. Clin Nutr Res 7(4): 229-240.

18. Monte SM, Wands JR (2008) Alzheimer's disease is type 3 diabetes- evidence reviewed. J Diabetes Sci Technol 2(6): 1101-1113.

19. Esra $A B$, Pinar $S$, Turan $A$. Insulin resistance in Alzheimer's disease. Alzheimer's Disease \& Treatment pp: 1-7.

20. Shaw K (2017) 'Type 3' diabetes: a brain insulinresistant state linked to Alzheimer's disease. Pract Diabetes 34(6): 187-188.

21. Steen E, Terry BM, Rivera EJ, Cannon JL, Neely TR, et al. (2005) Impaired insulin and insulin-like growth factor expression and signaling mechanisms in Alzheimer's disease- is this type 3 diabetes?. J Alzheimers Dis 7(1): 63-80.

22. Crous-Bou M, Minguillón C, Gramunt N, Molinuevo LJ (2017) Alzheimer's disease prevention: from risk factors to early intervention. Alzheimers Res Ther 9: 71.

23. Andrade S, Ramalho MJ, Loureiro JA, Preira MC (2019) Natural compound for Alzheimer's disease therapy: A systematic review of preclinical and clinical studies. Int J Mol Sci 20(9): 2313.

24. Nigam V, Nambiar VS (2017) Knowledge, practice and use of Aegle marmelos (L.) Correa leaves leaves among neuropathy and ayurvedic practitioners of vadodara city and desk review on various commercial 


\section{Open Access Journal of Pharmaceutical Research}

formulations available in health and disease specially diabetes. Int J Phytomed 9(3): 451-460.

25. Sanghi SB, Mushtaq S (2017) Aegle marmelos a potential medicinal tree: an overview. Int J Res Granthaalayah 5(8): 63-66.

26. Kala CP (2006) Ethnobotany and ethnoconservation of Aegle marmelos (L.) Correa. Indian J Trad knowl 5(4): 537-540.

27. Devika R, Koilpillai J (2012) An overview of plant secondary metabolites: its medicinal importance. J Pharm Res 5(2): 984-986.

28. Kabera NJ, Semana E, Mussa AR, He X (2014) Plant secondary metabolites: Biosynthesis, classification, function and pharmacological properties. J Pharm Pharmacol 2(7): 377-392.

29. Patel AR, Dipak G, Manodeep C, Jagdish KV (2012) Aegle marmelos (Linn.): A therapeutic boon for human health. Int J Res Ayurveda Pharm 3(2): 159163.

30. Yadav NP, Chanotia CS (2009) Phytochemical and pharmacological profile of leaves of Aegle marmelos Linn. The Pharma Review pp: 144-150.

31. Riyanto S, Sukari MS, Rahmani M, Gwendoline CLE, Taufiq-Yap YH, et al. (2001) Alkaloids from Aegle marmelos (Rutaceae). Malaysian J Anal Sci 7(2): 463465.

32. Bhar K, Mondal S, Suresh P (2019) An eye-catching review of Aegle marmelos L. (Golden Apple). Pharmacogn J 11(2): 207-224.

33. Kumar KPS, Umadevi M, Bhowmik D, Sing DM, Dutta AS (2012) Recent trends in medicinal uses and health benefits of Indian traditional herbs Aegle marmelos. Pharma Innovation 1(4): 57-65.

34. Patkar AN, Desai NV, Ranage AA, Kalekar KS (2012) A review on Aegle marmelos: a potential medicinal tree. Int Res J Pharm 3(8): 86-91.

35. Ibrahim NA, El-Sakhawy FS, Mohammed MMD, Farid MA, Abdel-Wahid N, et al. (2015) Chemical composition, antimicrobial and antifungal activities of essential oils of the leaves of Aegle marmelos (L.) Correa growing in Egypt. J Appl Pharm Sci 5(2): 1-5.
36. Verma RS, Padalia RC, Chauhan A (2014) Essential oil composition of Aegle marmelos (L.) Correa: Chemotypic and seasonal variation. J Sci Food Agr 94(9): 1904-1913.

37. Raheja S, Girdhar A, Kamboj A, Lather V, Pandita D (2019) Aegle marmelos leaf extract ameliorates the cognitive impairment and oxidative stress induced by intracerebroventricular streptozotocin in male rats. Life Sci 221: 196-203.

38. Karim SM, Rahman MM, Shahid SB, Malek I, Rahman AM, et al. (2011) Medicinal plants used by the folk medicinal practitioners of Bangladesh: a randomized survey in a village of Narayanganj district. Am.-Eur J Sustain Agr 5(4): 405-414.

39. Sharma K, Shukla S, Chauhan ES (2016) Evaluation of Aegle marmelos (Bael) as hyperglycemic and hyperlipidemic diminuting agent in type II diabetes mellitus subjects. Pharma Innovation 5(5): 43-46.

40. Khan MH, Yadava PS (2010) Antidiabetic plants used in Thoubal district of Manipur, Northeast India. Indian J Trad Knowl 9(3): 510-514.

41. Chakravarty S, Kalita JC (2012) An investigation on antidiabetic medicinal plants used by villagers in Nalbari District, Assam, India. Int J Pharm Sci Res 3(6): 1693-1697.

42. Joshi K, Joshi R, Joshi AR (2011) Indigenous knowledge and use of medicinal plants in Macchegaun, Nepal. Indian J Trad Knowl 10(2): 281286.

43. Ijinu TP, Anish N, Shiju H, George V, Pushpangadan P (2011) Home gardens for nutritional and primary health security of rural poor of South Kerala. Indian J Trad Knowl 10(3): 413-428.

44. Parmar N, Singh S, Patel B (2016) Historical and ethno-medical review on Bilvia (Aegle marmelos Corr.). J Res Trad Med 2(5): 138-146.

45. Haque T, Uddin MZ, Hasan AM, Saha ML (2017) Plants used for the treatment of diabetes in Brahmanbaria, Bangladesh. Clin Exp Homeopath 4(3): 8-18.

46. Aadhan K, Anand SP (2017) Survey of medicinal plants used for the treatment of diabetes by the Paliyar's Tribe in Sadhuragiri Hills, Tamil Nadu, India. Int J Herb Med 5(3): 17-25. 


\section{Open Access Journal of Pharmaceutical Research}

47. Kirtikar KR, Basu BD (1995) Indian Medicinal Plant. Int Book Pub 1: 499-502.

48. Rahman S, Parvin R (2014) Therapeutic Potential of Aegle marmelos (L.)- An overview. Asian Pac J Trop Dis 4(1): 71-77.

49. Adavala PD, Musukula YR, Puchchakayala G (2016) Neuroprotective effect of Aegle marmelos leaf extract in scopolamine induced cognitive impairment and oxidative stress in mice. Global J Pharmacol 10(2): 45-53.

50. Swarnkar R, Singh D, Choudhary A, Anand S, Rathore A, et al. (2019) Pharmacological properties of Aegle marmelos: A review. Int J Curr Microb Appl Sci 8(5): 1600-1608.

51. Asaduzzaman M, Uddin JM, Kader MA, Alam AHMK, Rahman AA, et al. (2014) In-vitro acetylcholinesterase inhibitory activity and the antioxidant properties of Aegle marmelos leaf extract: implications for the treatment of Alzhemer's disease. Psychogeriatrics 14(1): 1-10.

52. Manandhar B, Paudel KR, Sharma B, Karki R (2018) Phytochemical profile and pharmacological activity of Aegle marmelos Linn. J Integr Med 16(3): 153-163.

53. Chavan A, Lakshmikantha RY, Satwadi PR (2012) Evaluation of nootropic activity of Aegle marmelos extract using different experimental models in rats. Int J Pharm Chem Biol Sci 2(4): 538-544.

54. Kiran M, Viswanadha Murty NVSM, Girija SV (2018) Study on nootropic activity of Aegle marmelos L. fruits. J Integral Sci 1(1): 7-11.

55. Paulbabu K, Singh KD, Prashanti P, Padmaja M (2015) Neuroprotective potential and Efficacy of neurodegenerative disorders of fruit extract of Aegle marmelos. Int J Pharm Pharm Sci 7(1): 155-159.

56. Himani, Pratap S, Verma RC, Leve S, Sachan A, et al. (2013) An experimental study to evaluate the effects of Aegle marmelos and its comparison with Piracetam on learning and memory in Wistar rats. Int J Pharm Sci Res 4(4): 1591-1597.

57. Patel PK, Sahu J, Sahu L, Prajapati NK, Dubey BK (2012) Aegle marmelos: A review on its medicinal properties. Int J Pharm Phytopharmacol Res 1(5): 332-341.
58. Mustafa SB, Akram M, Muhammad Asif H, Qayyum I, Hashmi AM, et al. (2019) Antihyperglycemic activity of hydroalcoholic extracts of selective medicinal plants Curcuma longa, Lavandula stoechas, Aegle marmelos, and Glycyrrhiza glabra and their polyherbal preparation in alloxan-induced diabetic mice. Dose Response 17(2).

59. Rajan S, Satish S, Shankar K, Pandeti S, Varshney S, et al. (2018) Aegeline inspired synthesis of novel $\beta 3-A R$ agonist improves insulin sensitivity in vitro and in vivo models of insulin resistance. Metab 85: 1-13.

60. Mudi SR, Akhter M, Biswas SK, Muttalib MA, Choudhury S, et al. (2017) Effect of aqueous extract of Aegle marmelos fruit and leaf on glycemic, insulinemic and lipidemic status of type 2 diabetic model rats. J Complement Integr Med 14(2).

61. Ansari P, Afroz N, Jalil S, Azad SB, Mustakim MG, et al. (2017) Anti-hyperglycemic activity of Aegle marmelos (L.) Corr. is partly mediated by increased insulin secretion, $\alpha$-amylase inhibition, and retardation of glucose absorption. J Pediatr Endocrinol Metab 30(1): 37-47.

62. Gautam S, Ishrat N, Singh R, Narender T, Srivastava AK (2015) Aegeline from Aegle marmelos stimulates glucose transport via Akt and Rac1 signaling, and contributes to a cytoskeletal rearrangement through PI3K/Rac1. Eur J Pharmacol 762: 419-429.

63. Kumar V, Ahmed D, Verma A, Anwar F, Ali M (2013) Umbelliferone $\beta$-D-galactopyranoside from Aegle marmelos (L.) Corr. An ethnomedicinal plant with antidiabetic, antihyperlipidemic and antioxidative activity. BMC Complement Altern Med 13: 273.

64. Gandhi GR, Ignacimuthu S, Paulraj MG (2012) Hypoglycemic and $\beta$-cells regenerative effects of Aegle marmelos (L.) Corr. Bark extract in streptozotocin-induced diabetic rats. Food Chem Toxicol 50(5): 1667-1674.

65. Saha S, Verma R (2011) Inhibitory potential of traditional herbs on $\alpha$-amylase activity. Pharm Biol 50(3): 326-331.

66. Narendhirakannan RT, Subramanian S (2010) Biochemical evaluation of the protective effect of Aegle marmelos (L.), Corr. leaf extract on tissue antioxidant defense system and histological changes 


\section{Open Access Journal of Pharmaceutical Research}

of pancreatic beta-cells in streptozotocin-induced diabetic rats. Drug Chem Toxicol 33(2): 120-130.

67. Ramesh B, Pugalendi KV (2006) Influence of umbelliferone on glycoprotein components in diabetic rats. Toxicol Mech Methods 17(3): 153-159.

68. Narender T, Shweta S, Tiwari P, Papi Reddy K, Khaliq $\mathrm{T}$, et al. (2007) Antihyperglycemic and antidyslipidemic agent from Aegle marmelos. Bioorg Med Chem Lett 17(6): 1808-1811.

69. Kesari AN, Gupta RK, Singh SK, Diwakar S, Watal G (2006) Hypoglycemic and antihyperglycemic activity of Aegle marmelos seed extract in normal and diabetic rats. J Ethnopharmacol 107(3): 374-379.

70. Upadhya S, Shanbhag KK, Suneetha G, Naidu BM, Upadhya S (2004) A study of hypoglycemic and antioxidant activity of Aegle marmelos in alloxan induced diabetic rats. Indian J Physiol Pharmacol 48(4): 476-480.

71. Kamalakkanan N, Rajadurai M, Prince PS (2003) Effect of Aegle marmelos fruits on normal and streptozotocin-diabetic Wistar rats. J Med Food 6(2): 93-98.

72. Phuwapraisirisan P, Puksasook T, Jong-Aramruang J, Kokpol U (2008) Phenylethylcinnamides: a new series of alpha-glucosidase inhibitors from the leaves of Aegle marmelos. Bioorg Med Chem Lett 18(18): 4956-4958.

73. Baglietto-Vargas D, Shi J, Yaeger MD, Ager R, LaFerla FM (2016) Diabetes and Alzheimer's disease crosstalk. Neurosci Biobehav Rev 64: 272-287.

74. Francx W, Llera A, Mennes M, Zwiers MP, Faraone SV, et al. (2016) Integrated analysis of gray and white matter alterations in attention-deficit/hyperactivity disorder. NeuroImage: Clinical 11: 357-367.
75. Rivera EJ, Goldin A, Fulmer N, Tavares R, Wands JR, et al. (2005) Insulin and insulin-like growth factor expression and function deteriorate with progression of Alzheimer's disease: link to brain reductions in acetylcholine. J Alzheimers Dis 8(3): 247-268.

76. Myint AA, Win KS, Aung Z (2013) Alzheimer's disease and type 2 diabetes mellitus: risk factors and effectiveness of antidiabetic agents in treatment of Alzheimer's disease. Sci J Clin Med 2(3): 114-121.

77. Vandal M, White PJ, Tremblay C, St-Amour I, Chevrier $G$, et al. (2014) Insulin reverses the high-fat-dietinduced increase in brain $A \beta$ and improves memory in an animal model of Alzheimer disease. Diabetes 63(12): 4291-4301.

78. Long-Smith CM, Manning S, McClean PL, Coakley MF, O'Halloran DJ, et al. (2013) The diabetes drug liraglutide ameliorates aberrant insulin receptor localization and signaling in parallel with decreasing both amyloid -b plaque and glial pathology in a mouse model of Alzheimer's disease. Neuromol Med 15(1): 102-114.

79. Chen J, Li S, Sun W, Li J (2015) Anti-diabetes drug pioglitazone ameliorates synaptic defects in $\mathrm{AD}$ transgenic mice by inhibiting cyclin-dependent kinase 5 activity. PloS One 10(4): e0123864.

80. McClean PL, Holscher C (2014) Lixisenatide, a drug developed to treat type 2 diabetes, shows neuroprotective effects in a mouse model of Alzheimer's disease. Neuropharmacol 86: 241-258.

81. Farshchi A, Ghiasi G, Farshchi S, Ghobadi AT (2011) The effect of chronic administration of Aegle marmelos seed extract on learning and memory in diabetic rats. Iran J Basic Med Sci 14(1): 42-48. 